\title{
Effectiveness and Institutional Conditions in Social Forestry Program: Case Study of Forest Village Community Institution (LMDH) Sumber Makmur, Forest Management Unit (KPH) Malang
}

\author{
Ramli Ramadhan*, Deni Firman Syah, Nugroho Tri Waskitho \\ Forestry Study Program, Faculty of Agriculture-Animal Husbandry, University of Muhammadiyah Malang. Malang, 65144, \\ Indonesia \\ ${ }^{*}$ Corresponding author. E-mail address: ramliramadhan@umm.ac.id
}

\section{ARTICLE HISTORY:}

Received: 6 October 2021 Peer review completed: 8 November 2021 Received in revised form: 15 November 2021 Accepted: 3 February 2022

\section{KEYWORDS:}

Forest Village Community Institution Institutional conditions Institutional effectiveness Social forestry

(C) 2022 The Author(s). Published by Department of Forestry, Faculty of Agriculture, University of Lampung in collaboration with Indonesia Network for Agroforestry Education (INAFE). This is an open access article under the CC BY-NC license:

https://creativecommons.org/licenses/by$\mathrm{nc} / 4.0 /$

\begin{abstract}
Changes in the Social Forestry or Perhutanan Sosial (PS) scheme have been made by the Ministry of Environment and Forestry of the Republic of Indonesia, particularly in the state-owned forestry enterprise (Perhutani) working area. A forestry partnership is one of the schemes being developed to replace the previous scheme, Community Forest Management (PHBM). However, increased PS area permits are not always accompanied by increased farmer trust and understanding of the program. This study aimed to determine the institution's effectiveness and institutional condition in the era of PS policy, which is currently a government priority program. One of the community groups granted a management permit is the Forest Village Community Institution (LMDH) Sumber Makmur, located in the Forest Management Unit (KPH) Malang. This study was conducted from December 2020 to March 2021 using a qualitative descriptive method as in-depth interviews and questionnaires with assessment indicators. Respondents were chosen randomly from the entire population using the Slovin formula. The results showed that the institutional effectiveness of LMDH Sumber Makmur still tended to decrease. The confidence level of farmers in the PS program was only around $28.9 \%$, and the level of understanding was $26.7 \%$. The results also showed a low percentage value of farmer participation, external support, the availability of facilities, and gender perspective. Consequently, the government needs to monitor institutions and community groups running PS programs to see institutional developments in each location. Institutional development is essential as an entrance for people to manage forests independently.
\end{abstract}

\section{Introduction}

The increase in Social Forestry or Perhutanan Sosial (PS) area in the current Indonesian president administration era was mentioned by Sahide et al. (2020a) as an explosion of PS policy in Indonesia. Fisher et al. (2019) explained that PS in Indonesia entered the third generation (2012current), influenced by the Indonesian government's policy to expand people's access to forest land by involving stakeholders. Previously, the current government (2014 to present) has prioritized PS by providing a PS area of around 12.7 million ha in 2021. So far, Indonesia has five PS schemes as Village Forest or Hutan Desa (HD), Community Forest or Hutan Kemasyarakatan 
(HKm), Community Plantatation Forest or Hutan Tanaman Rakyat (HTR), Forestry Partnership (Kemitraan Kehutanan), and Customary Forest (Hutan Adat) (Fisher et al. 2018). Until 2021, 4.721 million ha of PS permits have been realized across all schemes (Direktorat Penyiapan Kawasan Perhutanan Sosial 2021). This achievement falls short of the government's goal of allocating 12.7 million ha for the PS area.

The PS program journey shows significant progress. The government's seriousness characterizes that by including PS in government regulations for the agenda of resolving tenure conflicts and access to long-term land management legally (Sahide et al. 2020b). This research began from changes in the regulation of the PS program, especially in the working area of the state-owned forestry company of Indonesia, known as Perhutani. The regulatory change stems from the Minister of Environment and Forestry Regulation (LHK) No. P.83 of 2016 on Social Forestry. Furthermore, the government issued a regulation of the Minister of LHK P.39 in 2017 on implementing unique PS in the Perhutani region. The implication of the regulation was the evaluation of the existing PS program in the Perhutani area through Community Joint Forest Management (Pengelolaan Hutan Bersama Masyarakat or PHBM system) (Ota 2019; Ragandhi et al. 2021; Supriyanto et al. 2021).

The Forest Village Community Institution or Lembaga Masyarakat Desa Hutan (LMDH) continues to use the Forestry Partnership Recognition and Protection or Pengakuan dan Perlindungan Kemitraan Kehutanan (Kulin-KK) scheme despite the change in regulation brought about by Government Regulation No. 23 of 2021 and Permen LHK No. 9 of 2021. With relatively rapid regulatory changes, Article 298 of the government regulation explains that management rights issued before the most recent regulations are declared to remain valid until the management rights expire. Rapid changes created obstacles in the field, particularly institutional and bureaucratic obstacles (Maryudi et al. 2022). LMDH Sumber Makmur must adjust to the new regulations, which are still being implemented. Therefore, the government encouraged the interaction of non-governmental organizations and other external actors to facilitate the development of community groups (Fisher et al. 2018; Rahayu et al. 2020). Especially now that community groups can manage forests through Forest Areas with Special Management or Kawasan Hutan Dengan Pengelolaan Khusus (KHDPK). In the Perhutani area, community groups partnering with Perhutani through the Kulin-KK scheme can switch to the Forestry Partnership scheme. Community groups can manage the forest through KHDPK outside the KHDPK area of Perhutani. On the other hand, our research site is still implementing the Kulin-KK scheme, although the regulations have changed. Changes in the structure of forest land governance that allow communities to obtain balanced management rights are very welcoming to the abovementioned new schemes (Ota 2019; Ragandhi et al. 2021).

However, improving the management of PS in Indonesia is currently facing challenges. One of the challenges in improving PS management is the institutional development of forest farmer groups (KTH) (Galudra 2019; Ibisono and Kartodihardjo 2019; Salaka et al. 2020). Furthermore, KTH institutions are limited to forming communities and reaching the jurisdiction boundaries over land, capital, policy support, external support, and democratic empowerment (Awang 2003).

The farmers' trust in LMDH and their understanding of the rules applied could be used to assess institutional effectiveness (Ohorella et al. 2011; Salaka et al. 2020). Furthermore, to determine the readiness of a community institution's condition, this study must include other indicators, such as external support from village governments, NGOs, local governments, and universities (Wulandari and Kurniasih 2019), access to capital and markets, and other supporting 
institutional business facilities. This study also included indicators of community involvement and gender. Community involvement in the process of developing land-use plans and participation in meeting activities are examples of farmer participation (Ruhimat 2017; Wulandari and Inoue 2018; Yeny and Suharti 2020). In contrast, gender engagement is linked to the role and voice of women farmers in determining forestry activities at LMDH Sumber Makmur (Dewi et al. 2020). It is also aligned with the current regulation, stating that gender is one of the criteria for evaluating PS implementation. Through a case study at LMDH Sumber Makmur located in Forest Management Unit (KPH) Malang, this study aims to analyze the effectiveness and condition of the institution in improving PS management. In line with the government's goal to grant PS permits, this research could contribute to the institutional assessment of community groups that gain access to forest management.

\section{Materials and Methods}

This study was conducted between December 2020 and March 2021, just before two regulations were issued in response to the Omnibus Law, namely Government Regulation (PP) No. 23 of 2021 and The Minister of Environment and Forestry Regulation No. 9 in 2021. As a result, the research was done before the social forestry policy change in Java after Omnibus Law. The Forestry Partnership Recognition and Protection (Kulin-KK scheme) under the Minister of Environment and Forestry Regulation No. 83 of 2016 is still in use at LMDH Sumber Makmur. The Kulin-KK scheme aims to form a Cooperation Agreement or Naskah Kesepakatan Kerjasama (NKK) between community groups and Perhutani (permit holder) and plan joint forest management and utilization. A plan for institutional strengthening and a business development plan was included in preparing a social forestry plan. Village involvement, non-governmental organizations (NGOs), local governments, universities, and business license holders listed in the regulations can all help prepare.

This study employed indicators, definitions, and measurement categories to determine how effective and ready institutional conditions followed the scheme's change (Table 1). The indicators developed were based on the criteria outlined in the current regulation for evaluating PS implementation thus far. In addition, to see the process of institutional readiness in implementing the PS program, we added indicators of participation and gender. The level of trust among farmer members and their understanding of the established rules, including Articles of Association or Anggaran Dasar dan Anggaran Rumah Tangga (AD/ART) and the NKK rules of the game, were used to assess institutional effectiveness. The facilitation indicators from outside actors in the context of strengthening institutional capacities, such as preparing the Social Forestry Group Plan (RKPS) and Annual Work Plan (RKT) (Ruhimat 2017), showed that institutional conditions are ready. It is stated in the regulation that community groups could obtain facilitation and access to business development through capital and markets in running the Social Forestry Business Group (KUPS).

Data analysis was conducted in a qualitative descriptive manner based on Table 1 to analyze the effectiveness of the Sumber Makmur LMDH institution and its current state by describing the phenomena that occurred in the field. In the Kulin-KK scheme, institutional effectiveness was measured by indicators of community trust and understanding of the applicable rules of the game. The proportion of respondents who say they believe, doubt, or do not believe was used to determine their level of trust. The categories of understand, quite understand, and do not 
understand were used to determine the respondents' level of understanding. The proportion of respondents, which included high, medium, and low categories, was used to determine the level of participation, external support, business development facilitation, and gender. The information was organized into categories based on indicators and measurements. The data was analyzed by dividing the frequency of respondents' responses by the total number of respondents and multiplied by $100 \%$ (Ibisono and Kartodihardjo 2019).

Table 1. Indicators of effectiveness and institutional conditions, definitions, and categories

\begin{tabular}{|c|c|c|c|}
\hline No. & Indicator & Definition & Measurement category \\
\hline 1 & $\begin{array}{l}\text { Level of } \\
\text { confidence }\end{array}$ & $\begin{array}{l}\text { Farmers' confidence in the benefits of PS to } \\
\text { improve the economy }\end{array}$ & $\begin{array}{l}\text { 1. Believe } \\
\text { 2. Hesitant } \\
\text { 3. Do not believe }\end{array}$ \\
\hline 2 & $\begin{array}{l}\text { Level of } \\
\text { understanding }\end{array}$ & Farmers' understanding of institutional rules & $\begin{array}{l}\text { 1. Understand } \\
\text { 2. Quite understand } \\
\text { 3. Do not understand }\end{array}$ \\
\hline 3 & Outside support & $\begin{array}{l}\text { Involvement of villages, NGOs, central } \\
\text { government, local governments, and } \\
\text { universities }\end{array}$ & $\begin{array}{l}\text { 1. High } \\
\text { 2. Moderate } \\
\text { 3. Low }\end{array}$ \\
\hline 4 & $\begin{array}{l}\text { Business } \\
\text { development } \\
\text { facilities }\end{array}$ & $\begin{array}{l}\text { Access to capital, business development, market } \\
\text { access }\end{array}$ & $\begin{array}{l}\text { 1. High } \\
\text { 2. Moderate } \\
\text { 3. Low }\end{array}$ \\
\hline 5 & Participation rate & $\begin{array}{l}\text { Farmers' participation in every institutional } \\
\text { activity }\end{array}$ & $\begin{array}{l}\text { 1. High } \\
\text { 2. Moderate } \\
\text { 3. Low }\end{array}$ \\
\hline 6 & Gender & $\begin{array}{l}\text { Women's involvement (management structure, } \\
\text { involvement in focused group discussions, } \\
\text { institutional activities }\end{array}$ & $\begin{array}{l}\text { 1. High } \\
\text { 2. Moderate } \\
\text { 3. Low }\end{array}$ \\
\hline
\end{tabular}

Notes: Indicators of outside support, support facilities, participation rates, and gender are contained in the regulation article 108, 111, and article 143 to see institutional conditions.

Based on Table 1, data analysis was carried out in a descriptive qualitative way to analyze the effectiveness of the LMDH Sumber Makmur institution and the condition by describing the phenomena that occurred in the field. Data was collected in the form of primary and secondary data. Primary data was obtained from in-depth interviews with selected respondents, LMDH administrators, and Perhutani, while secondary data was obtained from a literature review. Interviews were conducted on $45 \mathrm{LMDH}$ farmer members from 160 registered farmer members. The sample size was determined using the Slovin formula with a 5\% margin of error.

\section{Results and Discussion}

\subsection{Benefits of the PS Program}

Poverty reduction, empowerment of forest user communities, and improved forest conditions are all important agendas in the PS policy (Maryudi 2012). Compared to the PHBM program which has been in place for a long time, changes in PS policy through government regulations provide opportunities for improvement (Supriyanto et al. 2021). One of the goals of improving current PS management is to gain access to more land and opportunities for institutional 
development (Ota 2019). PHBM, which was previously a PS program from Perhutani, was considered unable to provide broad access to forest land and increase institutional capacity (Maryudi 2012; Maryudi and Krott 2012; Pratama 2019; Raharjo et al. 2020). Through this regulation, LMDH Sumber Makmur applied for a PS permit again under a forestry partnership scheme. This scheme requires LMDH and Perhutani to rearrange the agreement we know as the NKK. The NKK is different from the Cooperation Agreement (PKS), which was previously used when it was still PHBM. Based on the regulation, PS license holders through LMDH are given a proportional profit sharing according to the agreement. Article 59 of the Ministerial Regulation No. 9 of 2021 explains that if the profit-sharing has not found rights and obligations, then the verification from the Ministry of Forestry and Environment (KLHK) will facilitate even the improvement of the NKK. Because community groups are not the main actors in management, PHBM has not provided proportional profit sharing to date (Djajanti 2006; Nomura 2008; Pratama 2019; Rosyadi and Sobandi 2014). Profit-sharing for LMDH timber yields a maximum of 25\% and $75 \%$ Perhutani, respectively. Only LMDH timber and non-timber yields allow for higher percentage yields (Septiana 2020; Yokota et al. 2014). Table 2 shows the differences between the PHBM program and the current PS program that benefit LMDH, particularly strengthening institutions based on applicable regulations and previous research on PHBM implementation.

Table 2. Benefits obtained by LMDH

\begin{tabular}{clcc}
\hline No. & Advantage & PHBM era & Current PS \\
\hline 1 & Share the results worth & - & available \\
2 & Technical guidance & available & available \\
3 & Institutional strengthening & - & available \\
4 & Business development, financing \& market access & - & available \\
5 & External support (local government, Pokja PPS, forestry & - & available \\
& extension agents, NGOs, universities) & & \\
\hline
\end{tabular}

Note: (-) not available.

As previously stated, the PHBM era did not show proportional profit-sharing in terms of profit-sharing. PHBM, on the other hand, has been shown to improve land management by providing technical guidance to LMDH (Damayatanti 2011; Fujiwara et al. 2012). However, in terms of institutional capacity, the PHBM era was less concerned with enhancing LMDH's institutional capacity (Raharjo et al. 2020). Furthermore, in PHBM, there is no business development or access for community groups to develop their production businesses. Perhutani appears to be in charge of meeting business objectives (Maryudi 2012; Pratama 2019; Rosyadi and Sobandi 2014). The external support factor has not been fully utilized, NGOs have not been involved, and the role of local governments has not been fully utilized (Wilujeng 2015). This is in contrast with the current regulations, which are highly likely to involve external actors.

\subsection{Institutional Effectiveness of Forest Village Communities}

\subsubsection{Farmers' trust level}

Institutional effectiveness in a forest community group could be achieved if the community had a high level of community trust, understanding, and compliance with the rules (Ohorella et al. 2011). The level of trust refers to LMDH's belief in the socio-economic and ecological benefits of 
managed forests. In contrast, the level of understanding and compliance refers to how well the community understands the rules of the game as an obligation that must be met, such as stated in the Annual Work Plan (Rencana Kerja Tahunan or RKT) (Ibisono and Kartodihardjo 2019; Salaka et al. 2020). As a result, the variables used in this study referred to farmers' confidence in the economic benefits of the PS program's existence and their level of understanding of the game's rules as compiled by the $\mathrm{AD} / \mathrm{ART}$ and NKK rules. Therefore, to determine the extent to which the institution is working, its effectiveness must be assessed.

According to Febryano et al. (2014), the level of trust and understanding could be seen in the community's participation and active support for the agreed-upon forest management rules. Furthermore, a high level of trust indicates that the board and its members constantly communicate. Institutional effectiveness also allows institutions to improve their human resource capacity by providing various training and counseling (Wulandari and Kurniasih 2019).

This subchapter explains institutional effectiveness through the level of farmers' confidence in economic benefits through the PS program. Table 3 shows that the level of confidence of farmers in the current PS program has not been able to provide confidence to provide better economic benefits to farmers. A total of $51.1 \%$ of the 45 respondents did not believe the LMDH institution could provide economic benefits to all farmers. Furthermore, $20 \%$ of respondents that doubt between believing and not believing could have an economic impact. On the other hand, $28.9 \%$ of farmers expressed confidence that the strengthening of LMDH in the PS era can make the maximum contribution to them.

Table 3. Farmers' level of trust in economic improvement

\begin{tabular}{lc}
\hline Respondents' Trust in Economic Benefits & Distribution of Respondents (\%) \\
\hline Believe & $28.9 \%$ \\
Hesitant & $20.0 \%$ \\
Do not believe & $51.1 \%$ \\
\hline
\end{tabular}

Note: Data were obtained from 45 respondents.

Farmers were skeptical for various reasons, such as the contribution of income from forest land has not been maximized to date. LMDH's contribution to facilitating access to both capital and facilitation was still minimal. Furthermore, their current land was insufficient to meet their daily needs, so they looked for side jobs outside of arable, such as farm laborers or breeders. On the other hand, farmers with a more established economic status believed that LMDH development could positively impact the economy. They were not entirely reliant on LMDH, but they believed it could support them. Those who believed in the majority also played a role in the management of LMDH. This tendency confirmed previous research (Gunawan 2013), stating that only active members were aware of LMDH and that participation was still limited. According to the findings, LMDH Sumber Makmur has not instilled trust in farmers in institutions that provide socioeconomic benefits. This tendency could affect farmers' confidence in LMDH as their forest manager. Government assistance in facilities, assistance, and business capital financing would be ineffective if member trust in LMDH were low.

\subsubsection{Farmer's level of understanding}

The indicator of farmers' level of understanding of the rules that apply in LMDH was the same. Table 4 shows that up to 26 farmers (57.8\%) did not understand the rules, particularly 
written rules such as $\mathrm{AD} / \mathrm{ART}$. The rest of 7 farmers $(15.5 \%)$ did not understand the rules of the game in LMDH, while 12 farmers (26.7\%) said they did understand. Most farmers who did not understand the written rules were from a middle to lower socio-economic background, the elderly, and farmers with only basic education (elementary school graduates). They believe that the rules have been established with the best interests of the institution and LMDH members in mind. Farmers who understand the rules of $\mathrm{AD} / \mathrm{ART}$, on the other hand, have a higher level of education and are members of the LMDH management. According to Wilujeng (2015), one of the challenges in implementing the PS program is that not all smallholders know the program and its rules. It indicated that forest management institutions were not performing to their full potential.

Table 4. Farmer's level of understanding of AD/ART and NKK

\begin{tabular}{lc}
\hline Farmers' understanding of written Rules & Distribution of respondents (\%) \\
\hline Understand & $26.7 \%$ \\
Quite understand & $15.5 \%$ \\
Do not understand & $57.8 \%$ \\
\hline
\end{tabular}

Note: Data were obtained from 45 respondents.

The level of understanding indicated that the main rules or regulations in an institution were only understood by administrators and some farmers with higher education who wished to advance their institution. On the other hand, the main rule was an agreement that must be agreed to and followed (Salaka et al. 2020). Table 4 shows that the LMDH Sumber Makmur was ineffective because farmers have not understood it. Furthermore, the permit holder showed no commitment to managing the forest as a whole, which includes institutional development.

\subsection{Institutional Conditions}

In this study, institutional conditions looked at several variables that impacted increasing institutional capacity (Wulandari and Kurniasih 2019), farmer participation, external support, and business development facilitation. We also included gender equality in article 107 of Forestry Regulation No. 9 of 2021 or previous regulations as an essential part of the regulation's continuation. Members of the LMDH must participate in determining how farmers were involved in each management activity. Participation was also linked to institutional effectiveness; the higher the participation, the greater the trust, understanding, and adherence to agreed-upon rules (Febryano et al. 2014).

External parties such as local governments, village governments, NGOs, and universities were also consulted about the situation. The involvement of external actors in the capacity building of community institutions is crucial (Galudra 2019; Supriono et al. 2013; Wulandari and Inoue 2018). Additionally, building institutional capacity through Article 108 facilitates group business development. Commodity or production development, capital access, or market access are all examples of facilitation. Therefore, to increase institutional capacity, it is necessary to consider whether LMDH receives facilitation to support business development. Finally, we looked at the search for gender in institutional formation as an indicator. The government regulates gender issues when evaluating the performance of PS management, such as the representation of women in management and their participation. 


\subsubsection{Rate of participation, external support, business development facilities}

We looked at the level of participation of farmers in the PS program and the involvement of external stakeholders who provide facilitation and facilitation in the context of business development to assess the institutional conditions (Sundar 2013; Supriyanto et al. 2021). These results agreed with Gunawan (2013), stating that community participation and support from related parties influenced an institution's role. Furthermore, LMDH should be aided in developing farming businesses through KUPS rather than relying solely on profit sharing. Article 114 of the Minister of Environment and Forestry Regulation No. 9 of 2021 calls for institutional strengthening through business improvement. Finally, institutional conditions must be examined from a gender perspective to determine women's participation, particularly in management structures and active participation in decision-making.

The participation of LMDH members in forest management activities could be involved in preparing work plans, implementing work, and evaluating activities being worked on (Liani et al. 2016). The exact definition of participation is related to the active involvement of several people in each stage of activities ranging from planning, implementation, and utilization (Yeny and Suharti 2020). The level of participation was reviewed from the beginning of the involvement in the planning process and decision-making meetings. Table 5 shows that the participation of members in PS activities was still relatively low, which ranged at 55.6\%. In comparison, farmers who were not so active only $4.4 \%$ and answered actively participating in activities was $40 \%$. Based on our interviews, farmers tend to be passive towards every institution activity due to age and education level. They believe in stewardship and are not active in every activity in LMDH. These members tend to passively accept what the manager conveys and do not try to ask or be directly involved in the activities process actively. At the same time, active farmers are young respondents and have relatively high education, so their willingness and ability to develop institutions is needed. For example, in coordination activities with Perhutani related to sharing revenue sharing, making $\mathrm{AD} / \mathrm{ART}$ institutions, and the preparation of $\mathrm{NKK}$ and making reports of results of activities periodically with Perhutani partners.

Table 5. Institutional conditions

\begin{tabular}{lcccc}
\hline \multicolumn{1}{c}{$\begin{array}{c}\text { Distribution } \\
\text { of respondents } \\
(\%)\end{array}$} & $\begin{array}{c}\text { Farmer } \\
\text { participation }\end{array}$ & Exernal support & $\begin{array}{c}\text { Business development } \\
\text { facilities }\end{array}$ & Gender \\
\hline High & 40.0 & 28.9 & 13.3 & 15.6 \\
Moderate & 4.4 & - & - & 11.1 \\
Low & 55.6 & 71.1 & 86.7 & 73.3 \\
\hline
\end{tabular}

Note: data were obtained from 45 respondents.

External support is also an important indicator to assess the readiness and institutional condition of the Sumber Makmur LMDH. External support is defined by the attention given by external actors such as villages, local governments, NGOs, universities, and the private sector (Sylviani et al. 2020). External support from the private sector and local government has an essential role in assessing institutional development (Ruhimat 2017; Wulandari and Inoue 2018). The PHBM era showed that the involvement of external actors as the central and local governments was very minimal (Wilujeng 2015). Maryudi (2012) stated that it was due to the enormous dominance of Perhutani. PS currently allows the involvement of many actors, for example, through 
the activation of the Working Group on the Acceleration of Social Forestry (Pokja PPS), where village governments, local governments, NGOs, and universities are included.

Table 5 shows that LMDH Sumber Makmur has not received any outside assistance to date. $71.1 \%$ of respondents said they did not receive any external support. Perhutani, which has become a partner, has provided the most support. Similarly, respondents who said they received much external help were still assisted by Perhutani. On the other hand, PS is currently more flexible due to external supports. The results showed that LMDH and the government that encouraged PS acceleration have not cooperated with outside parties to help institutional strengthening. One of them is the support of the village government. This study found that the role of the village government in supporting the PS program was very minimal. The reason was that many villages had not included the state forest area in the village planning. They used the state forest instead of the area in the authority of the village government. However, the LMDH area was factually included in the village administration area (Yuwono and Novianto 2018). In contrast, Law No. 6 of 2014 on village stated that villages have authority in the field, such as implementing village development and community empowerment. Village funds are one of the budget instruments that LMDH could be accessed for their activities. However, the results showed that LMDH Sumber Makmur had not received support from the village government. NGO assistance was also not found, even though NGOs usually become a bridge to support outside parties.

The facilities referred to here are assistance in business development, access to business capital, and market access. The Minister of Environment and Forestry Regulation No. 9 of 2021 Article 108 stated that the activity plan includes institutional strengthening and business development, including access to marketing and capital. However, according to data from respondents, $86.7 \%$ answered that there had been no facilitation in institutional strengthening so far. Facilitation came from Perhutani, a partner since the PHBM program, such as assistance for pine seedlings. Most farmer members in LMDH earned their income from collecting pine resins on Perhutani lands. In addition, farmers also received assistance from extension personnel regarding the management of agricultural commodities such as corn and cassava.

External support is linked to aspects of business development, particularly in the formation of farming cooperatives (Supriono et al. 2013). However, this study revealed that the number of facilities available for LMDH development was minimal. As a result, the activities of LMDH could be hampered, and farmers will not develop forest or farming businesses if the institution's readiness to prepare facilities is minimal.

\subsection{Gender Perspective}

The participation of women farmers in institutional activities is one of the most important indicators of institutional conditions at LMDH Sumber Makmur. Gender participation in institutional activities could be seen from respondents' responses to women's participation in all meetings and decision-making processes. While Leone (2019) shows that the effectiveness of an institution depends on its gender composition, greater emphasis should be placed on the collective placement of women within the institution. Previous studies showed that women continue to be under-represented in institutional activities (Catacutan and Naz 2015; Dewi et al. 2020; Nhem and Lee 2019). Men are primarily in charge of forest resources, ranging from socio-political activities to valuable ones that can be sold on the market, such as timber (Agarwal 2009). Table 5 shows that $73.3 \%$ of women's participation in institutional activities was still deficient, with only $15.6 \%$ 
of farmers responding that women play an active role. The majority of those who responded were LMDH administrators themselves. According to $11.1 \%$ of respondents, women did attend meetings, but they did not play a significant role, especially in decision-making. The condition is contrary to the research results of Wulandari and Inoue (2018), stating that women have significant roles in supporting sustainable forest management through PS. So far, women's participation in management has been primarily in reproductive and productive activities (firewood, animal feed, and non-timber products), while socio-political activities that determine institutional plans were very rare (Dewi et al. 2020; Marin and Kuriakose 2017). Socio-cultural norms often made it difficult for women to participate in PS programs, which is one factor that supports this (UNREDD 2011; Wulandari and Inoue 2018).

Fig. 1 shows that the LMDH management structure is dominated by men from the chairman to the member below him, with no female representation. The results indicated that the gender perspective was still not used. However, Minister of Environment and Forestry Regulation No. 9 of 2021 concerning Social Forestry Management has included articles number 90, 107, and 189 on a gender perspective because the role of women has been increasingly neglected so far. Furthermore, Ray et al. (2017) showed that involving women in decision-making could have a positive effect since women are more conservation-minded and pro-social than men.

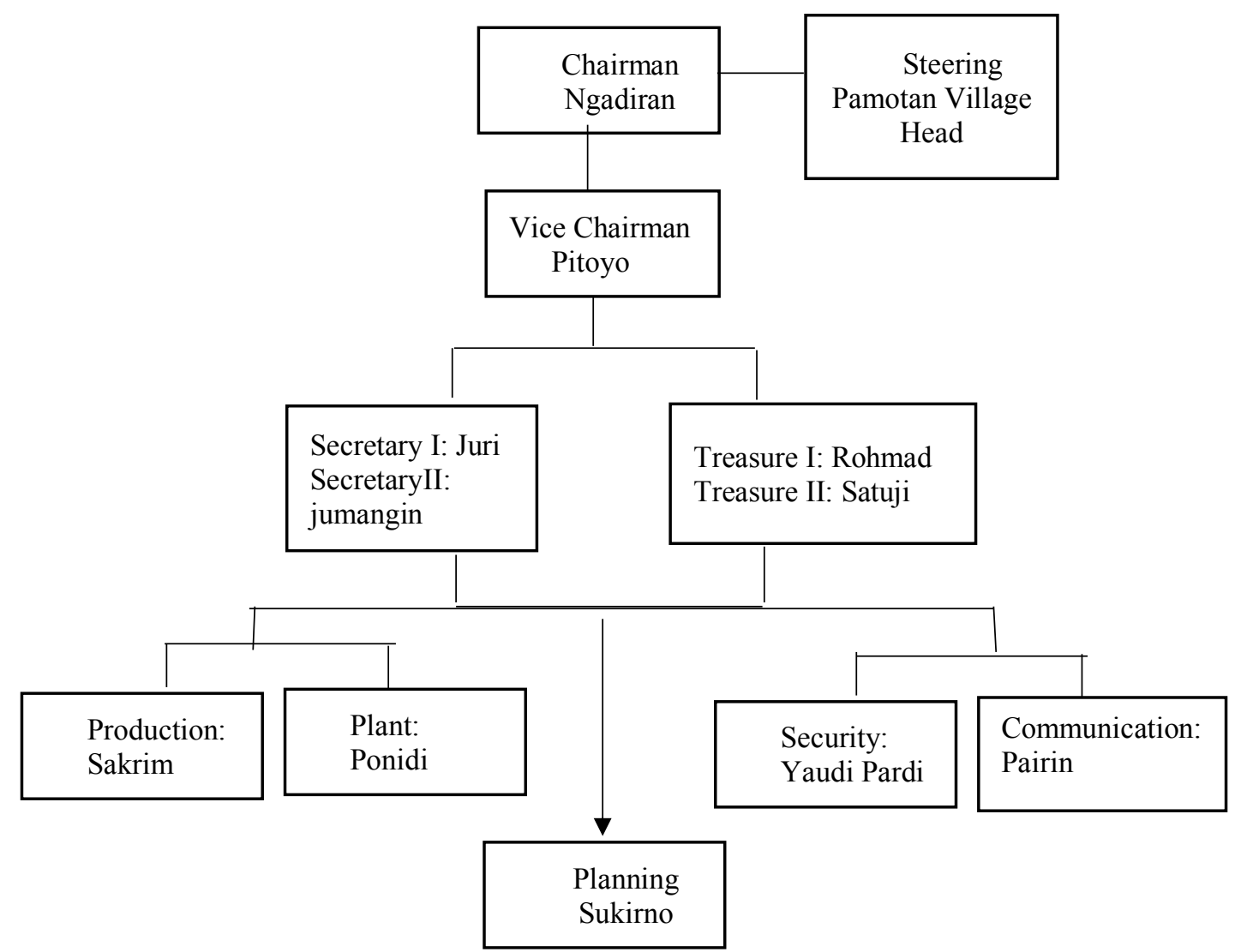

Fig. 1. Management structure of LMDH Sumber Makmur.

Furthermore, gender studies revealed that women spend more time on land than men (Akter et al. 2017; Catacutan and Naz 2015). On the other hand, women are responsible for the household and husband. However, it does not guarantee that they are officially registered under their given name (Dewi et al. 2020). As a result, women have significantly less access to control land resources than men (Agarwal 2009; Vázquez-García and Ortega-Ortega 2017). The loss of women's 
participation in activities and management demands research on women's participation in institutions and forest management, which is still limited.

\section{Conclusions}

The findings of this study indicated that the institutional effectiveness of LMDH Sumber Makmur was still low. The results showed that only $28.9 \%$ of respondents believe that the existing PS program may offer economic benefits, affecting the farmers' confidence in LMDH management. The farmer's level of understanding was also low, showing only $26.7 \%$ of farmers understand the institution's rules of the game, indicating that LMDH Sumber Makmur has not communicated with farmer members. Additionally, the variable of farmer engagement showed that $55.6 \%$ of farmer members participated in institutional activities. The results also revealed that the supports from external stakeholders were still minimal. Finally, the gender equality indicator demonstrated that men dominate, particularly in institutional activities and management structures. This study suggested that the government needs to monitor institutions and community groups running PS programs to see institutional developments in each location. Institutional development is essential as an entrance for people to manage forests independently.

\section{Acknowledgments}

The authors thank the Head of LMDH and Mantri Perhutani, who provided access to information and data. The authors also thanks to UMM for funding this research through DPPM.

\section{References}

Agarwal, B. 2009. Gender and Forest Conservation: The Impact of Women's Participation in Community Forest Governance. Ecological Economics 68(11): 2785-2799. DOI: 10.1016/j.ecolecon.2009.04.025

Akter, S., Rutsaert, P., Luis, J., Htwe, N. M., San, S. S., Raharjo, B., and Pustika, A. 2017. Women's Empowerment and Gender Equity in Agriculture: A Different Perspective from Southeast Asia. Food Policy 69: 270-279. DOI: 10.1016/j.foodpol.2017.05.003

Awang, S. A. 2003. Politik Kehutanan Masyarakat. Center for Critical Social Studies (CCSS). Yogyakarta.

Catacutan, D., and Naz, F. 2015. Introduction: Contributions and Gaps in Gender and Agroforestry. International Forestry Review 17(4): 1-10. DOI: $10.1505 / 146554815816086471$

Damayatanti, P. T. 2011. Upaya Pelestarian Hutan melalui Pengelolaan Sumberdaya Hutan Bersama Masyarakat. Jurnal Komunitas 3(1): 70-82.

Dewi, K. H., Raharjo, S. N. I., Desmiwati, Hendarto, K. A., Aminah, A., Wisudayati, T. A., Royani, H., Hasibuan, A. D. S., and Sari, D. R. 2020. Roles and Voices of Farmers in the "Special Purpose" Forest Area in Indonesia: Strengthening Gender Responsive Policy. Asian Journal of Women's Studies 26(4): 444-465. DOI: 10.1080/12259276.2020.1844972

Direktorat Penyiapan Kawasan Perhutanan Sosial. 2021. Rencana Kerja Direktorat PKPS Tahun 2021. Jakarta.

Djajanti, D. 2006. Managing forest with Community (PHBM) in Central Java: Promoting Equity 
in Access to NTFPs. Hanging in the Balance: Equity in Community-Based Natureal Resource Management in Asia. Regional Community Forestry Training Center for Asia and the Pacific. 63-82.

Febryano, I. G., Suharjito, D., Darusman, D., Kusmana, C., and Hidayat, A. 2014. The Roles and Sustainability of Local Institutions of Mangrove Management in Pahawang Island. Jurnal Manajemen Hutan Tropika 20(2): 69-76. DOI: 10.7226/jtfm.20.2.69

Fisher, M. R., Dhiaulhaq, A., and Sahide, M. A. K. 2019. The Politics, Economics, and Ecologies of Indonesia's Third Generation of Social Forestry: An Introduction to the Special Section. Forest and Society 3(1): 152-170. DOI: 10.24259/fs.v3i1.6348

Fisher, M. R., Moeliono, M., Mulyana, A., Yuliani, E. L., Adriadi, A., Kamaluddin, Judda, J., and Sahide, M. A. K. 2018. Assessing the New Social Forestry Project in Indonesia: Recognition, Livelihood and Conservation? International Forestry Review 20(3): 346-361. DOI: $10.1505 / 146554818824063014$

Fujiwara, T., Septiana, R. M., Awang, S. A., and Tri, W. 2012. Changes in Local Social Economy and Forest Management through the Introduction of Collaborative Forest Management (PHBM), and the Challenges It Poses on Equitable Partnership: A Case Study of KPH Pemalang, Central Java, Indonesia. Japan Society of Tropical Ecology 20(4): 115-134. DOI: 10.3759/tropics.20.115

Galudra, G. 2019. Focusing on Facilitation: Issues and Challenges of Capacity Development in Indonesia's Social Forestry Reforms. Forest and Society 3(1): 133-136. DOI: $10.24259 /$ fs.v3i1.5995

Gunawan, K. S. 2013. Implementasi Program Pengelolaan Sumberdaya Hutan Bersama Masyarakat Dalam Perspektif Pemberdayaan Masyarakat Desa Hutan di Kabupaten Blora. Tesis. Universitas Hasanudin. Makassar.

Ibisono, R. A. A., and Kartodihardjo, H. 2019. Kelembagaan Hutan Rakyat Studi Kasus Kelompok Tani Taruna Tani Desa Karyasari Kecamatan Leuiliang Bogor. Risalah Kebijakan Pertanian dan Lingkungan: Rumusan Kajian Strategis Bidang Pertanian dan Lingkungan 4(3): 226238. DOI: 10.20957/jkebijakan.v4i3.25999

Leone, M. 2019. Women as Decision Makers in Community Forest Management: Evidence from Nepal. Journal of Development Economics 138: 180-191. DOI: 10.1016/j.jdeveco.2019.01.002

Liani, M. F., Roslinda, E., and Muin, S. 2016. Partisipasi Masyarakat Dalam Pengelolaan Hutan Adat Di Dusun Sungai Utik Desa Batu Lintang Kecamatan Embaloh Hulu Kabupaten Kapuas Hulu. Jurnal Hutan Lestari 4(3): 273-281. DOI: 10.26418/jhl.v4i3.15815

Marin, A. B., and Kuriakose, A. T. 2017. Gender and Sustainable Forest Management: Entry Points for Design and Implementation. Climate Investment Funds. 20p.

Maryudi, A. 2012. Restoring State Control Over Forest Resources through Administrative Procedures: Evidence from a Community Forestry Programme in Central Java, Indonesia. Austrian Journal of South-East Asian Studies 5(2): 229-242. DOI: 10.4232/10.aseas-5.2-3

Maryudi, A., and Krott, M. 2012. Poverty Alleviation Efforts through a Community Forestry Program in Java, Indonesia. Journal of Sustainable Development 5(2): 43-53. DOI: 10.5539/jsd.v5n2p43

Maryudi, A., Sahide, M. A. K., Daulay, M. H., Yuniati, D., Syafitri, W., Sadiyo, S., and Fisher, M. R. 2022. Holding Social Forestry Hostage in Indonesia: Contested Bureaucracy Mandates and Potential Escape Pathways. Environmental Science and Policy 128(1): 142- 
153. DOI: $10.1016 /$ j.envsci.2021.11.013

Nhem, S., and Lee, Y. J. 2019. Women's Participation and the Gender Perspective in Sustainable Forestry in Cambodia: Local Perceptions and the Context of Forestry Research. Forest Science and Technology 15(3): 93-110. DOI: 10.1080/21580103.2019.1595174

Nomura, K. 2008. The Politics of Participation in Forest Management: A Case from Democratizing Indonesia. Journal of Environment and Development 17(2): 166-191. DOI: $10.1177 / 1070496507312598$

Ohorella, S., Suharjito, D., and Ichwandi, I. 2011. Efektivitas Kelembagaan Lokal dalam Pengelolaan Sumber Daya Hutan pada Masyarakat Rumahkay di Seram Bagian Barat, Maluku. Jurnal Manajemen Hutan Tropika 17(2): 49-55.

Ota, M. 2019. From Joint Forest Management to More Smallholder-Based Community Forestry : Prospects and Challenges in Java, Indonesia. Journal of Forest Research 24: 1-5. DOI: 10.1080/13416979.2019.1685063

Pratama, A. A. 2019. Lessons Learned from Social Forestry Policy in Java Forest: Shaping the Way Forward for New Forest Status in ex-Perhutani Forest Area. Jurnal Ilmu Kehutanan 13(2): 127-136. DOI: 10.22146/jik.52092

Ragandhi, A., Hadna, A. H., Setiadi, S., and Maryudi, A. 2021. Why Do Greater Forest Tenure Rights Not Enthuse Local Communities? An Early Observation on the New Community Forestry Scheme in State Forests in Indonesia. Forest and Society 5(1): 159-166. DOI: 10.24259/fs.v5i1.11723

Raharjo, S. A. S., Hastanti, B. W., and Haryanti, N. 2020. Dinamika Kelembagaan Perhutanan Sosial di Wilayah Pehutani: Studi Kasus di KPH Telawa, Jawa Tengah. 11(2): 183-197. DOI: 10.14710/politika.11.2.2020.183-197

Rahayu, S., Laraswati, D., Pratama, A. A., Sahide, M. A. K., Permadi, D. B., Wibowo, W., Widyaningsih, T. S., Suprapto, E., Andayani, W., and Maryudi, A. 2020. Bureaucratizing Non-Government Organizations as Governmental Forest Extension Services in Social Forestry Policy in Indonesia. Forests Trees and Livelihoods 29(2): 119-129. DOI: $10.1080 / 14728028.2020 .1753585$

Ray, B., Mukherjee, P., and Bhattacharya, R. N. 2017. Attitudes and Cooperation: Does Gender Matter in Community-Based Forest Management? Environment and Development Economics 22(5): 594-623. DOI: 10.1017/s1355770x16000358

Rosyadi, S., and Sobandi, K. R. 2014. Relasi Kuasa antara Perhutani dan Masyarakat dalam Pengelolaan Sumberdaya Hutan di Banyumas: Kepentingan Bisnis Vs Community Empowerment. Komunitas: International Journal of Indonesian Society and Culture 6(1): 47-56. DOI: 10.15294/komunitas.v6i1.2939

Ruhimat, I. S. 2017. Peningkatan Kapasitas Kelembagaan Kelompok Tani Dalam Pengembangan Usahatani Agroforestry: Studi Kasus Di Desa Cukangkawung, Kecamatan Sodonghilir, Kabupaten Tasikmalaya, Provinsi Jawa Barat. Jurnal Penelitian Sosial dan Ekonomi Kehutanan 14(1): 1-17. DOI: 10.20886/jsek.2017.14.1.1-17

Sahide, M. A. K., Fisher, M. R., Erbaugh, J. T., Intarini, D., Dharmiasih, W., Makmur, M., Faturachmat, F., Verheijen, B., and Maryudi, A. 2020a. The Boom of Social Forestry Policy and the Bust of social Forests in Indonesia: Developing and Applying an Access-Exclusion Framework to Assess Policy Outcomes. Forest Policy and Economics 120: 102290. DOI: 10.1016/j.forpol.2020.102290

Sahide, M. A. K., Fisher, M. R., Supratman, S., Yusran, Y., Pratama, A. A., Maryudi, A., Runtubei, 
Y., Sabar, A., Verheijen, B., Wong, G. Y., and Kim, Y. S. 2020b. Prophets and Profits in Indonesia's Social Forestry Partnership Schemes: Introducing a Sequential Power Analysis.

Forest Policy and Economics 115: 102160. DOI: 10.1016/j.forpol.2020.102160

Salaka, F. J., Alviya, I., Suryandari, E. I., Nurfatriani, F., and Muttaqin, M. Z. 2020. Efektivitas

Kelembagaan Pengelolaan Hutan Tanaman Rakyat di Tingkat Lokal. Jurnal Analisis Kebijakan Kehutanan 17(1): 75-92.

Septiana, R. M. 2020. Benefit Sharing Allocation on Community Collaborative Forest Management (PHBM) in Java, Indonesia. Jurnal Silva Tropika 4(1): 206-221.

Sundar, B. 2013. An Analysis of the Property Rights of Forest Dependent Communities: The Indian Context. Vikalpa 38(3): 79-102. DOI: 10.1177/0256090920130306

Supriono, A., Bowo, C., Kosasih, A. S., and Herawati, T. 2013. Strategi Penguatan Kapasitas

Kelompok Tani Hutan Rakyat di Kabupaten Situbondo. Jurnal Penelitian Hutan Tanaman 10(3): 139-146. DOI: 10.20886/jpht.2013.10.3.139-146

Supriyanto, H., Sudarmo, S., and Setyowati, K. 2021. Implementation of Social Forestry in Perum Perhutani KPH Telawa. Jurnal Analisis Kebijakan Kehutanan 18(1): 31-43.

Sylviani, S., Suka, A. P., Surati, S., and Kurniasari, D. R. 2020. Social Capital in Managing Community Plantation Forest: A Case Study at KPH Boalemo, Gorontalo Province. Indonesian Journal of Forestry Research 7(1): 71-82. DOI: 10.20886/ijfr.2020.7.1.71-82

UN-REDD. 2011. The Business Case for Mainstreaming Gender in REDD+. FAO, UNDP and UNEP. 8-9p.

Vázquez-García, V., and Ortega-Ortega, T. 2017. Gender, Local Governance and Non Timber Forest Products. The Use and Management of Satureja macrostema in Oaxaca's Central Valleys, Mexico. Women's Studies International Forum 65: 47-52. DOI: 10.1016/j.wsif.2016.08.003

Wilujeng, E. 2015. Implementasi Kebijakan Pengelolaan Hutan Bersama. Jurnal Kebijakan dan Manajemen Publik 3(1): 1-10.

Wulandari, C., and Inoue, M. 2018. The Importance of Social Learning for the Development of Community Based Forest Management in Indonesia: The Case of Community Forestry in Lampung Province. Small-Scale Forestry 17(3): 361-376. DOI: 10.1007/s11842-018-93927

Wulandari, C., and Kurniasih, H. 2019. Community Preferences for Social Forestry Facilitation Programming in Lampung, Indonesia. Forest and Society 3(1): 114-132. DOI: 10.24259 /fs.v3i1.6026

Yeny, I., and Suharti, S. 2020. Partisipasi Masyarakat dalam Pengembangan Agroforestri di Kesatuan Pengelolaan Hutan (KPH) Gedong Wani. Jurnal Penelitian Sosial dan Ekonomi Kehutanan 17(1): 49-66.

Yokota, Y., Harada, K., Rohman, Silvi, N. O., Wiyono, Tanaka, M., and Inoue, M. 2014. Contributions of Company-Community Forestry Partnerships (PHBM) to the Livelihoods of Participants in Java, Indonesia: A Case Study in Madiun, East Java. Japan Agricultural Research Quarterly 48(3): 363-377. DOI: 10.6090/jarq.48.363

Yuwono, T., and Novianto, E. 2018. Belajar dari Tapak Perhutanan Sosial. Kerjasama Direktorat Jenderal Pembangunan dan Pemberdayaan Masyarakat Desa, Kementerian Desa, Pembangunan Daerah Tertinggal dan Transmigrasi dengan Fakultas Kehutanan Universitas Gadjah Mada. Yogyakarta. 